\title{
Nicotinic Cholinergic Signaling in Adipose Tissue and Pancreatic Islets Biology: Revisited Function and Therapeutic Perspectives
}

\author{
Emmanuel Somm
}

Received: 4 July 2013/ Accepted: 14 November 2013/Published online: 26 November 2013

(C) L. Hirszfeld Institute of Immunology and Experimental Therapy, Wroclaw, Poland 2013

\begin{abstract}
Nicotinic acetylcholine receptors (nAChRs) are membrane ligand-gated cation channels whose activation is triggered by the binding of the endogenous neurotransmitter acetylcholine or other biologic compounds including nicotine. Their roles in synaptic transmission in the central and peripheral nervous system as well as in the neuromuscular junction have been extensively studied. Recent implications of nAChRs in intracellular signaling and their detection in peripheral nonneural cells (including epithelial cells and immune cells) have renewed the interest for this class of ionotropic receptors. In the present review, we focus our attention on the potential use of nicotinic cholinergic signaling in the treatment of metabolic diseases (such as obesity and diabetes) in browsing functions of $\mathrm{nAChRs}$ in adipose tissue and pancreatic islet biology. In fact, different $\mathrm{nAChR}$ subunits can be detected in these metabolic tissues, as well as in immune cells interacting with them. Various rodent models of obesity and diabetes benefit from stimulation of the nicotinic cholinergic pathway, whereas mice deficient for some nAChRs, in particular the $\alpha 7 \mathrm{nAChR}$ subunit, harbor a worsened metabolic phenotype. In contrast to potential therapeutic applications in metabolic diseases, an overstimulation of this signaling pathway during the early stage of development (typically through nicotine exposure during fetal life) presents deleterious consequences on ontogeny and functionality of adipose tissue and the endocrine pancreas which persist throughout life.
\end{abstract}

Keywords Nicotine $\cdot \mathrm{nAChR} \cdot$ Islet $\cdot$ Adipocyte Obesity · Diabetes

\section{E. Somm (ه)}

Division of Development and Growth, Department of Paediatrics, University of Geneva School of Medicine, 1211 Geneva 14, Switzerland

e-mail: emmanuel.somm@unige.ch

\author{
Abbreviations \\ $\mathrm{ACh}$ \\ $\mathrm{AChE}$ \\ AKT \\ AMPK \\ BAT \\ ChAT \\ CREB \\ DIO \\ DOHaD \\ FFA \\ F-FDG \\ GDP \\ IL \\ Acetylcholine \\ Acetylcholinesterase \\ Protein kinase B \\ AMP-activated protein kinase \\ Brown adipose tissue \\ Choline acetyltransferase \\ cAMP response element-binding protein \\ Diet-induced obesity \\ Developmental Origins of Health and \\ Disease \\ JAK2/STAT3 Janus kinase 2 and signal transducer and \\ activator of transcription 3 \\ MCP-1 Monocyte chemoattractant protein-1 \\ nAChR Nicotinic acetylcholine receptor \\ NPY Neuropeptide Y \\ PI3-kinase Phosphatidylinositide 3-kinase \\ POMC Proopiomelanocortin \\ PPAR- $\gamma \quad$ Peroxisome proliferator-activated receptor \\ gamma \\ SNP Single nucleotide polymorphism \\ T1D Type 1 diabetes \\ TNF- $\alpha \quad$ Tumor necrosis factor alpha \\ UCP-1 Uncoupling protein 1 \\ WAT White adipose tissue
}

\section{Sum-up of Nicotinic Cholinergic Signaling Biology}

Acetylcholine $(\mathrm{ACh})$ is a small organic molecule initially discovered by H.H. Dale and later identified by O. Loewi as the first neurotransmitter. Dale and Loewi jointly 
received in 1936 the Nobel Prize in physiology or medicine for their discoveries "relating to chemical transmission of nerve impulses" (Raju 1999). ACh is synthesized intracellularly by the enzyme choline acetyltransferase (ChAT) from choline and acetyl-coenzyme A before being released into the extracellular space to act on synaptic-adjacent cells. In contrast, the enzyme acetylcholinesterase (AChE) can rapidly clear the extracellular ACh pool into its inactive metabolites choline and acetate. This signaling system is targeted by various biological modulators which can, for example, inhibit ACh release or AChE activity. Sensitivity to natural $\mathrm{ACh}$ mimetics has allowed deciphering between two different cholinergic signaling pathways. Muscarine, a poisonous molecule found in mushrooms, induces a strong activation of the peripheral parasympathetic nervous system (muscarinic syndrome) that can end in convulsions and death. Nicotine, a natural alkaloid produced by the tobacco plant, is one of the most widely consumed psychostimulants, inducing strong behavioral dependence. These two molecules act via distinct types of cholinergic receptors. The muscarinic ACh receptors (AChRs M1-5) consist of a family of five metabotropic or second messenger-coupled receptors (Eglen 2012; Ishii and Kurachi 2006). On the other hand, the nicotinic AChRs (nAChRs) consist of a family of ligand-gated cation channels (Albuquerque et al. 2009; Changeux 2012). Purification of protein extracts and electronic microscopy have revealed amino acid sequence and size of nAChR (Changeux et al. 1970; Changeux 1990) before later cloning revealed the chromosomal location of a total of 16 genes coding for different nAChR subunits in mammalian genomes: $9 \alpha$ subunits (CHRNA $1-7$, CHRNA 9-10), $4 \beta$ subunits (CHRNB 1-4) and 3 atypical $\gamma, \delta, \varepsilon$ subunits (CHRNG, CHRND, CHRNE) (Albuquerque et al. 2009). These genes are probably from a common ancestor through a duplication and mutation process, since they are highly conserved throughout evolution (Le Novere and Changeux 1995). The pentameric structure initially described (Hucho and Changeux 1973) and confirmed by refined modeling at 4A resolution (Unwin 2005) consists of a symmetrical arrangement of the five subunits around a central pore. Each subunit possesses four transmembrane domains with their $\mathrm{N}$ - and C-terminus located extracellularly. nAChRs can be classically subclassed as muscular or neuronal. The muscular $\mathrm{nAChR}$ is a heteropentameric protein composed of $(\alpha 1)_{2}, \beta 1, \delta, \gamma$ subunits in the fetus and $(\alpha 1)_{2}, \beta 1, \delta, \varepsilon$ subunits in the adult. The neuronal nAChRs can be heteropentamerics, resulting from the assembly of different subunits with at least one of them being $\alpha$, or homopentameric when composed of five identical $\alpha$ subunits (typically the $\alpha 7 \mathrm{nAChR}$ ). The subunit composition of nAChRs determines their expression pattern, function and pharmacologic properties (such as agonist sensitivity or desensitizing period) (Hogg et al.
2003; Hurst et al. 2013; Lindstrom 1996). Functionally, non-muscular nAChRs are generally categorized as highaffinity nicotine binding receptors (integrating $\alpha 4$ subunits), $\alpha$-bungarotoxin-sensitive neuronal nAChRs (composed of an $\alpha 7$ subunit) and ganglionic receptors (composed of $\alpha 3$ and $\beta 4$ subunits) (Hogg et al. 2003; Hurst et al. 2013; Lindstrom 1996). Mechanistically, $\alpha 7$ nAChRs are opened by relatively low nicotine concentrations, but then rapidly desensitized contrary to $\alpha 3 / \beta 4$ nAChR receptors, insensitive to low nicotine concentrations and slow to desensitize (Hogg et al. 2003; Hurst et al. 2013; Lindstrom 1996). Ionic selectivity also differentiates nAChRs, since $\alpha 7$ nAChR specifically presents high permeability to $\mathrm{Ca}^{2+}$ exceeding that of other nAChRs (Hogg et al. 2003; Lindstrom 1996; Uteshev 2012). These features and advances in understanding the structural/functional properties of $\alpha 7$ nAChRs through new techniques have recently suggested its use as a new pharmacotherapeutic target (Palma et al. 2012; Taly and Charon 2012).

Beyond their channeling activity, nAChRs can be involved in other intracellular events involving signaling through PI3-kinase (Huang et al. 2012; Kihara et al. 2001), ERK1/2 (Dajas-Bailador et al. 2002), AKT (Nakayama et al. 2002; West et al. 2003) and CREB (Brunzell et al. 2003) pathways. Other regulatory roles for nAChRs have also been described in proteolysis (Meyer et al. 2002; Minana et al. 1998) and mitochondrial permeability (Gergalova et al. 2012). In addition to their classic roles of neurotransmitter in the central nervous system, neuromuscular junction and autonomic nervous fibers, several studies have detected nAChR expression in many different non-neuronal cell types throughout the body (for review see Conti-Fine et al. 2000; Gahring and Rogers 2005; Sharma and Vijayaraghavan 2002). These observations have led to reconsidering the role of ACh not only as a neurotransmitter, but also as a paracrine messenger able to interact with peripheral nAChRs. In this context, the interaction between $\mathrm{ACh}$ released by the vagus nerve and $\alpha 7 \mathrm{nAChR}$ expressed on macrophages/immune cells (Wang et al. 2003) represents a "cholinergic anti-inflammatory pathway" (Tracey 2007) of particular clinical interest. There is increasing evidence that smokers have a lower incidence of certain bowel inflammations (Lakhan and Kirchgessner 2011) and that use of the cholinergic anti-inflammatory pathway can present valuable therapeutic perspectives in a wide range of pathologies including sepsis, endotoxemia, ischemia/reperfusion injury, hemorrhagic shock, rheumatoid arthritis and other conditions of excessive cytokine release (Oke and Tracey 2009; Tracey 2007).

The present review aims to evaluate the function and the potential therapeutic perspectives of peripheral cholinergic signaling through nAChRs with special focus on adipose 
and pancreatic islet biology, two tissues involved in metabolic diseases. To this purpose, we then summarize and discuss: (1) peripheral detection of different subunits composing nAChRs, (2) experimental results from animal/ cell models exposed to nAChR agonists/antagonists and (3) basal or challenged phenotypes of animals deficient in some nAChR subunits, in the context of adipose tissue and pancreatic islet physiology and their commonly associated pathologies: obesity and diabetes.

\section{Nicotinic Cholinergic Signaling in Brown and White Adipose Tissue Biology and Therapeutic Perspectives in the Treatment of Obesity}

White adipose tissue (WAT) functions as a reservoir of energy stored as triglycerides after a meal and released into the bloodstream as fatty acids and glycerol between meals. WAT also acts as a thermal insulator and possesses endocrine functions, secreting many adipokines (cytokines produced by adipose tissue) involved in the regulation of body weight homeostasis and insulin sensitivity (Harwood 2012).

Brown adipose tissue (BAT) is especially abundant in newborns and in hibernating mammals, but recent studies have revealed its persistence in human adults (Cypess et al. 2009; van Marken Lichtenbelt et al. 2009). BAT, which is more innervated and vascularized than WAT, is the main site of adaptative thermogenesis, a process of heat production independent of muscular shivering (Lowell and Spiegelman 2000).

White and brown adipocytes present morphologic and molecular features corresponding to their distinct functional roles. In white adipocytes, triglyceride storage is unilocular (a single lipid droplet is present in the cytosol) and mitochondria are small and elongated, with randomly oriented cristae. In contrast, in brown adipocytes, triglyceride storage is multilocular (numerous intracellular small lipid droplets) and mitochondria are large, numerous, endowed with laminar cristae and specifically express the uncoupling protein 1 (UCP-1) responsible for uncoupling of the oxidative phosphorylation that in turn is responsible for heat production (Cinti 2005, 2012; Frontini and Cinti 2010).

Peripheral nicotinic cholinergic signaling could be involved in adipose tissue biology through localization of nAChRs at various levels, such as in autonomic ganglia, macrophages, or directly in adipocytes. Studies on knockout mice have demonstrated that combinations of $\alpha 3$ with $\beta 2$ or $\beta 4$ subunits compose most nAChRs in autonomic ganglia of the sympathetic nervous system (Wang et al. 2002) which control adipose tissue activity. Macrophages, mediating the cholinergic anti-inflammatory pathway through the $\alpha 7 \mathrm{nAChR}$ (Wang et al. 2003), are responsible for the inflammatory response in WAT during obesity (Weisberg et al. 2003; Xu et al. 2003) and also secrete local catecholamines during adaptative thermogenesis in BAT (Nguyen et al. 2011). Adipose tissue possesses functional cholinergic signaling machinery as shown by its regulated expression of butyrylcholinesterase (Wang et al. 2011). Moreover, various nAChR subunits can be detected in isolated adipocytes (Liu et al. 2004), as well as in BAT and WAT from rodents (Gochberg-Sarver et al. 2012) and humans (Cancello et al. 2012).

\section{Nicotine Exposure Effects}

\section{In Humans}

Epidemiological studies dealing with the metabolic action of tobacco consumption represent an extensive source of information, nevertheless difficult to interpret in the context of nicotinic cholinergic action on the adipose metabolism due to both the simultaneous central and peripheral action of nicotine and the large panel of bioactive compounds accompanying nicotine in tobacco (Borgerding and Klus 2005). Selective and focal nicotine exposure through microdialysis is an interesting technique used to directly study in vivo nicotinic cholinergic signaling on the human adipose metabolism. In healthy subjects, this route of nicotine administration causes a concentration-dependent and reversible increase in the levels of glycerol release, whereas the opposite effect is induced by carbachol, demonstrating a dual effect of the nicotinic/ muscarinic cholinergic system on lipolysis (Andersson and Arner 1995). In healthy male smokers, acute nicotine infusion increases free fatty acid (FFA) release in adipose tissue consecutively to an oral glucose tolerance test (Eliasson et al. 1997). This technique also shows that nicotine-induced increase in venous, arterial and adipose glycerol occurs with no change in blood flow (Andersson and Arner 2001), suggesting an induction of lipolysis through activation of the classical adrenergic mechanism and by activation of a nicotinic cholinergic lipolytic receptor located in the adipose tissue (Andersson and Arner 2001).

\section{In Control Animals}

In basal physiologic conditions, changes in body fat proportion parallels changes in body weight in response to nicotine exposure in rats, suggesting that nicotine administration decreases body weight by lowering fat stores in the body (Winders and Grunberg 1990). Central anorexigenic features of nicotine (for review see Jo et al. 2002; Li et al. 2000b; Zoli and Picciotto 2012) can in part explain 
dampening of adipose storage. In fact, numerous hypothalamic neuropeptides involved in the control of food intake are regulated by nicotinic cholinergic signaling. Nicotine increases neuropeptide Y (NPY) in different hypothalamic areas (Jang et al. 2003; Li et al. 2000a), but limits elevation of NPY during food restriction (Jang et al. 2003). Ex vivo, nicotine directly induces depolarization of NPY neurons and reduces their glutamatergic input (Huang et al. 2011). Nicotine also increases expression of orexin and its receptor in the hypothalamus (Kane et al. 2000), but decreases orexin binding (Kane et al. 2001) and induces fos expression in some orexin neuron subpopulations (Pasumarthi et al. 2006), linked with the release of glutamate and $\mathrm{ACh}$ in the lateral hypothalamus (Pasumarthi and Fadel 2010). Nicotine also induces release of hypothalamic monoamines (Fu et al. 2001; Meguid et al. 2000; Sharp and Matta 1993; Yang et al. 1999), indirect inhibition of melanin-concentrating hormone neurons (through activation of GABAergic transmission) (Jo et al. 2005), direct stimulation of proopiomelanocortin (POMC) neurons (Huang et al. 2011; Mineur et al. 2011) and inactivation of hypothalamic AMP-activated protein kinase (AMPK) (Martinez de Morentin et al. 2012). Different nAChRs seem to mediate nicotine inhibition of food intake. In the lateral hypothalamus, neuronal webs receive cholinergic afferents and express $\alpha 4 / \beta 2$ and $\alpha 7 \mathrm{nAChRs}$ (Jo et al. 2002; Seguela et al. 1993; Wada et al. 1989). $\alpha 3 / \beta 4$ nAChRs seem rather implicated in both nicotinic cholinergic stimulation of POMC neurons (Mineur et al. 2011) and inactivation of hypothalamic AMPK (Martinez de Morentin et al. 2012). Interestingly, despite that leptin receptor isoform $\mathrm{b}$ and $\alpha 7$ nAChRs share the same JAK2/STAT3 downstream effectors (de Jonge et al. 2005; Hakansson and Meister 1998; Kloek et al. 2002; Vaisse et al. 1996), and despite the known effects of nicotine on feeding behavior, the relationship between $\alpha 7 \mathrm{nAChRs}$ and leptin sensitivity remains unexplored. The JAK2/STAT3 activation by $\alpha 7 \mathrm{nAChR}$ stimulation (by nicotine or more specific agonists) in situations of leptin resistance, as seen in obesity, may represent a new approach to control feeding behavior.

Beyond these central effects indirectly impacting adipose tissue through limitation of energy intake, nicotine also directly impacts WAT and BAT metabolism. Nicotine does not seem to alter the composition of the major fatty acids in adipose triglycerides (Brindis et al. 1973), but induces a fall in the respiratory quotient (Bishop et al. 2004; Martinez de Morentin et al. 2012) reflecting a rise in lipid use. Nicotine induces a fall in circulating triglyceride levels associated with decreased adipose tissue lipoprotein lipase activity (Chajek-Shaul et al. 1987; Sztalryd et al. 1996). By increasing basal lipolysis, but blunting the lipolytic response to sympathomimetic $\beta$-receptor stimulant isoproterenol, nicotine appears to divert fat storage from adipose tissue toward utilization by the muscle (Sztalryd et al. 1996). Nicotine administration also interferes with the endocrine function of adipose tissue by decreasing circulating leptin levels (Arai et al. 2001) and gene expression in the perirenal and epididymal WAT ( $\mathrm{Li}$ and Kane 2003). Nicotine-induced weight loss is associated with increased BAT thermogenesis and increased energy expenditure (Martinez de Morentin et al. 2012). Acute and chronic exposure to nicotine increases both the turnover of norepinephrine and the binding of the guanosine- $5^{\prime}$ diphosphate (GDP) to BAT mitochondria (Lupien and Bray 1988). Decreased vacuolation, elevated UCP-1 and norepinephrine contents are also observed in BAT in a depotspecific manner following nicotine administration (Arai et al. 2001; Brees et al. 2008). Nicotine induces uptake of ${ }^{18} \mathrm{~F}-\mathrm{FDG}$ in BAT (blockable by a prior injection of $\beta$ adrenergic antagonists) (Baba et al. 2007) and a reversible noradrenaline release from BAT (blockable by antagonism of corticotrophin-releasing factor receptor type 1) (ManoOtagiri et al. 2009).

\section{In Obesity Models}

Lipolytic and thermogenic features of nicotinic cholinergic signaling previously described in the basal state led to evaluate its potential weight loss promoting action in different rodent models of obesity. Genetically obese ob/ob mice subcutaneously injected with nicotine present a rise in plasma FFA with no change in basal body temperature or cold-induced hypothermia (Batt and Topping 1979). In monosodium-L-glutamate obese mice, nicotine treatment attenuates obesity in the absence of food intake modification by significantly increasing norepinephrine turnover, GDP binding/oxygen consumption in BAT and the resting metabolic rate (Yoshida et al. 1990). Obese yellow KK mice chronically treated with nicotine present decreased weight, smaller subcutaneous and retroperitoneal WAT depot harboring multilocular cells and ectopic UCP-1 gene expression leading to the mitigation of obesity (Yoshida et al. 1999). In Zucker fatty rats, the tumor necrosis factor (TNF)- $\alpha$ level is specifically lowered in visceral fat pads (Liu et al. 2001) in response to nicotine administration. In genetically obese mice with a defective leptin receptor $(\mathrm{db} /$ $\mathrm{db}$ ) as well as in diet-induced obese (DIO) mice, nicotine does not change body weight or appetite, but reduces the inflammation of adipose tissue depots through activation of the cholinergic anti-inflammatory pathway (Wang et al. 2011). In DIO mice, treatment with galantamine (an AChE inhibitor enhancing cholinergic signaling and also acting as a positive allosteric modulator of $\alpha 7 \mathrm{nAChR}$ ) (Albuquerque et al. 2001) significantly reduces body weight, food intake, abdominal adiposity, plasma cytokine and adipokine levels, and significantly improves blood glucose, 
insulin resistance and hepatic steatosis (Satapathy et al. 2011). These results suggest that galantamine has both a central and a peripheral anti-inflammatory effect (Satapathy et al. 2011). In conclusion, various rodent models of obesity can benefit from activation of the nicotinic cholinergic signaling pathway (Table 1).

nAChR Subunits Involved and Genetic Models

Quantification of nAChR subunits in adipose tissue or adipose cells from rodents and humans (summarized in Table 2) as well as metabolic phenotyping of animal models harboring a deficiency in nAChR subunits also contribute to deeper understanding of the role of the nicotinic cholinergic pathway in adipose tissue development and function. Gene expression of $\alpha 1-7, \alpha 9, \alpha 10, \beta 1-4, \delta$ and $\varepsilon \mathrm{nAChR}$ subunits can be detected in rat adipocytes, in line with immunocytochemical labeling of $\alpha 7$ and $\beta 2$ subunits (Liu et al. 2004). Functional binding of labeled nicotine directly on adipocytes corroborate functionality of these adipose nAChRs (Liu et al. 2004). In mice, the expression pattern of nAChR subunits in WAT $(\alpha 2>\alpha 5>\beta 2>\alpha 4)$ diverges from that of BAT $(\alpha 2>\beta 2>\beta 4>\alpha 5)$ (Gochberg-Sarver et al. 2012) suggesting depot-specific functional roles. In link with these basic observations, single nucleotide polymorphism (SNP) in the $\alpha 2 \mathrm{nAChR}$ subunit appears as a risk factor for overweight/obesity in a human cohort (Kim 2008). Genetic deletion of AChE (as well as administration of AChE pharmacological inhibitors) induces hypothermia associated with reduced nicotinic receptor currents in isolated sympathetic ganglia neurons mediating the activation of BAT (Sun et al. 2007). Chronic nicotine treatment decreases gene expression of TNF- $\alpha$, adiponectin and monocyte chemoattractant protein-1 (MCP-1) in WAT and those of TNF- $\alpha$ and adiponectin in BAT (Gochberg-Sarver et al. 2012). $\beta 2 \mathrm{nAChR}$ subunit deficiency ( $\beta 2 \mathrm{nAChR}{ }^{-/-}$ mice) affects gene expression of cyclooxygenase 2 and nerve growth factor $\beta$ in WAT and those of leptin, cyclooxygenase 2, adiponectin and haptoglobin in BAT suggesting a role for this subunit in regulation of gene transcription in adipose tissue (Gochberg-Sarver et al. 2012). The cholinergic anti-inflammatory pathway also seems to play an important role in obesity-induced inflammation of adipose tissue. In fact, metabolic phenotype of $\alpha 7 \mathrm{nAChR}^{-1-}$ mice shows that their macrophages present elevated proinflammatory cytokine production in response to FFAs (Wang et al. 2011). Nicotine significantly suppresses FFA- and TNF- $\alpha$-induced cytokine production in wild-type but not in $\alpha 7 \mathrm{nAChR}^{-/-}$macrophages, suggesting that $\alpha 7 \mathrm{nAChR}$ mediates the anti-inflammatory effect of nicotine (Wang et al. 2011). Inactivation of the cholinergic anti-inflammatory pathway in the $\alpha 7$
$\mathrm{nAChR}{ }^{-1-}$ mouse model results in increased adipose tissue infiltration of classically activated M1 macrophages and inflammation leading to impaired insulin sensitivity independent of any change in body weight (Wang et al. 2011). These experimental observations in rodents are strikingly highlighted by the recent investigations on $\alpha 7 \mathrm{nAChR}$ subunits in human WAT. $\alpha 7 \mathrm{nAChR}$ expression appears lowered in the subcutaneous adipose tissue of obese humans compared with that of control subjects (Cancello et al. 2012). In isolated mature adipocytes from highly obese subjects, $\alpha 7 \mathrm{nAChR}$ expression and protein content are $75 \%$ lower compared with control subjects, whereas weight loss induces an increase in $\alpha 7 \mathrm{nAChR}$ expression (Cancello et al. 2012).

\section{Cell Culture}

Some molecular mechanisms involved in nicotinic cholinergic signaling in fat cells are more thoroughly elucidated through in vitro experiments using adipocyte cell lines or primary cultures. Exposure of 3T3L1 adipocytes to nicotine increases lipolysis and inhibits fatty acid synthase activity, phosphorylating both AMPK and acetylCoA carboxylase (An et al. 2007). These effects appear to be mediated through induction of reactive oxygen species (An et al. 2007). In rat adipocyte primary culture, nicotine induces a dose-responsive release of TNF- $\alpha$, adiponectin and FFA into the medium (Liu et al. 2004). In contrast, TNF- $\alpha$ protein levels decrease in adipocytes, suggesting that nicotine regulates time dependently the production and secretion of adipokines (Liu et al. 2004). In mice adipocyte primary cultures, application of nicotine after silencing the $\beta 2 \mathrm{nAChR}$ subunit significantly elevates the expression level of cyclooxygenase- 2 gene, corroborating a molecular link between the $\beta 2 \mathrm{nAChR}$ subunit and the expression levels of specific adipokines also affected by nicotine (Gochberg-Sarver et al. 2012). In vitro stimulation of human adipocytes with the specific $\alpha 7 \mathrm{nAChR}$ agonist PNU282987 induces a significant anti-inflammatory effect, decreasing the pro-inflammatory up-regulation of interleukin (IL)-6, MCP-1 and TNF- $\alpha$ genes induced by lipopolysaccharide (Cancello et al. 2012). Likewise, a genistein treatment inducing an increase in $\alpha 7 \mathrm{nAChR}$ protein content results in a significantly decreased expression of IL-6 and MCP-1 genes in adipocyte culture (Cancello et al. 2012).

\section{Early Deleterious Programming Action}

The programming phenomenon [also known as the Barker's Hypothesis or Developmental Origins of Health and Disease $(\mathrm{DOHaD})$ theory] is a biological process underlying developmental plasticity. This concept of "fetal 


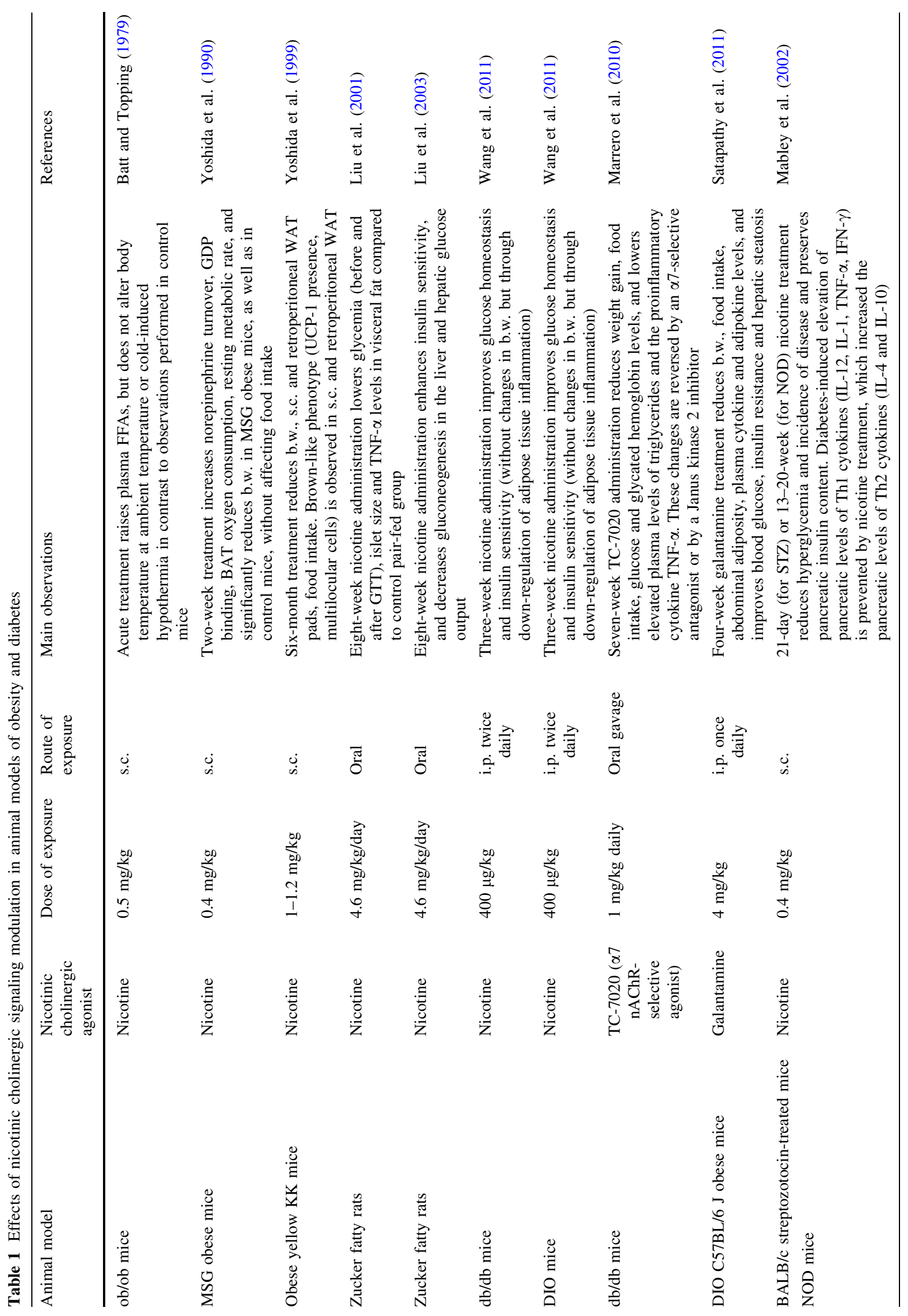




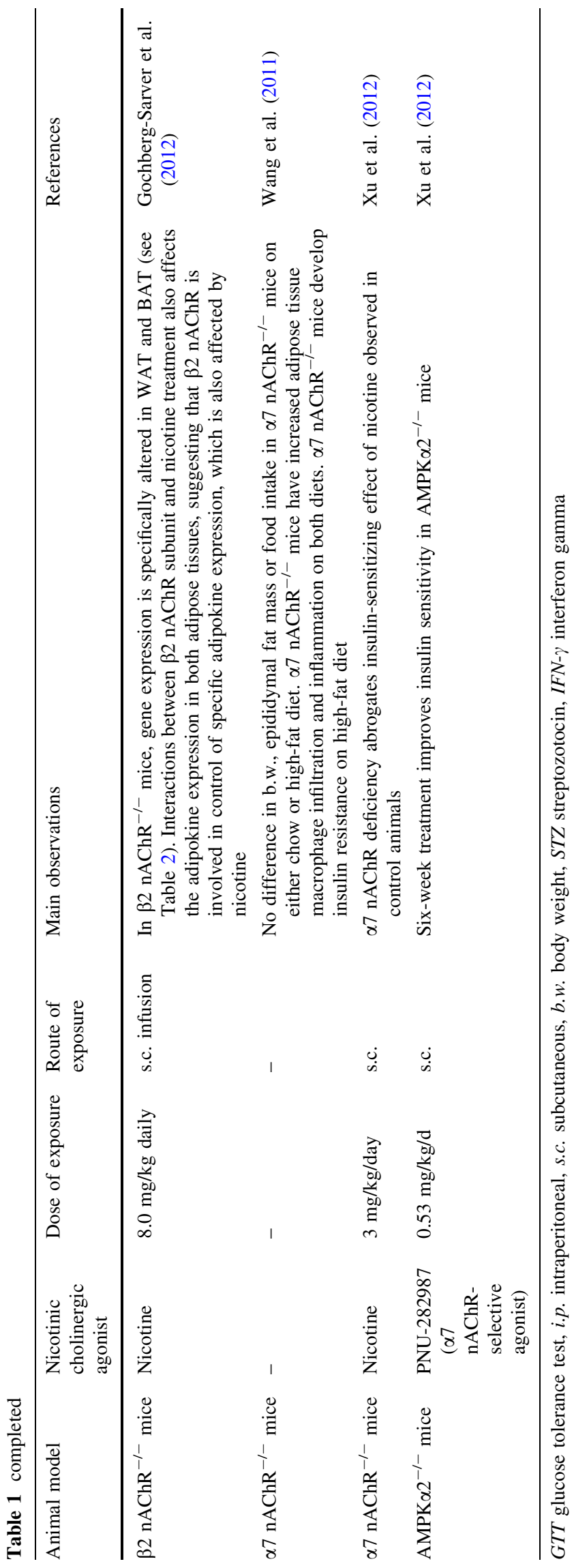

origin of adult diseases" suggests that a mismatch between fetal expectation of the postnatal environment and actual postnatal environment could contribute to later adult disease risk (Gluckman and Hanson 2004). For example, maternal inadequate nutrition, which limits fetal growth leading to low birth weight, predisposes to obesity in adulthood, especially when postnatal nutrition is highly caloric (Hales and Barker 1992). Voluntary or passive exposure to chemical pollutants also contribute to inadequate intrauterine environment, and despite medical advice more than $10 \%$ women continue smoking during pregnancy (for review see Somm et al. 2009). In contrast to the direct lipolytic and anti-inflammatory action of nicotinic cholinergic signaling previously discussed, fetal nicotinic exposure seems to present an opposite effect by programming excessive adipose tissue development later in life. Epidemiological studies have correlated maternal smoking during pregnancy with increased risk of obesity in children at different ages (Al Mamun et al. 2006; Koupil and Toivanen 2008; Mizutani et al. 2007; Ong et al. 2002; Power and Jefferis 2002; Sowan and Stember 2000; Toschke et al. 2002a, b). Animal studies show that nicotine exposure mimics the effect of maternal tobacco consumption on obesity occurrence in the offspring (for review see Somm et al. 2009). Initial observations showing elevation in body fat proportion by one-third just before birth in rat fetuses prenatally exposed to nicotine (Williams and Kanagasabai 1984) are corroborated by more recent studies. Epididymal, mesenteric and perirenal fat pad weights are increased in adulthood in Wistar rats perinatally exposed to nicotine (Gao et al. 2005). Epididymal fat pad weight is also heavier at weaning in Sprague-Dawley rats exposed to nicotine during their uterine life, mainly due to enhanced differentiation of their adipocytes (Somm et al. 2008). Prenatal nicotine exposure also exacerbates post-weaning weight gain and fat deposition caused by high-fat diet consumption (Somm et al. 2008). Maternal nicotine exposure restricted to the lactating period also leads to early and late metabolic defects. Higher levels of HDL-C, leptin, corticosterone and adrenal catecholamine content are observed at PND15, (Oliveira et al. 2010) and overweight (with increased fat mass and hypertrophy of adipocyte), hyperleptinemia (with impaired hypothalamic leptin signaling), hyperinsulinemia and hypothyroidism are reported in adult rat offspring exposed to nicotine through maternal milk (de Oliveira et al. 2010). Different mechanisms could explain the enhanced adipose storage due to early nicotine exposure during the early stage of development such as (1) increased release and transport of fatty acids from maternal adipose tissue to the fetal circulation (Williams and $\mathrm{Ka}$ nagasabai 1984), (2) a nicotine-mediated stimulatory effect on PPAR- $\gamma$ gene expression in the adipocyte (Somm et al. 2008), as previously observed in monocytes (Amoruso 
Table 2 Detection of nAChR subunits in adipose or pancreatic islet cells and tissues

\begin{tabular}{|c|c|c|c|c|c|}
\hline Tissue/cell line & Specie & nAChR subunits & $\begin{array}{l}\text { Method of } \\
\text { detection }\end{array}$ & Remarks & References \\
\hline \multicolumn{6}{|l|}{ Adipose tissue } \\
\hline Epididymal WAT & Mice & $\alpha 2>\alpha 5>\beta 2>\alpha 4$ & qPCR & $\begin{array}{l}\text { In } \beta 2 \mathrm{nAChR}^{-1-} \text { mice, the expression levels of } \operatorname{Cox} 2 \text { and } \\
\mathrm{Ngf} \beta \text { genes are significantly altered in WAT }\end{array}$ & $\begin{array}{l}\text { Gochberg-Sarver } \\
\text { et al. (2012) }\end{array}$ \\
\hline Interscapular BAT & Mice & $\alpha 2>\beta 2>\beta 4>\alpha 5$ & qPCR & $\begin{array}{c}\text { In } \beta 2 \mathrm{nAChR}^{-1-} \text { mice, the expression levels of Leptin, Cox } 2 \text {, } \\
\text { AdipoQ and haptoglobin are significantly altered in BAT }\end{array}$ & $\begin{array}{l}\text { Gochberg-Sarver } \\
\text { et al. (2012) }\end{array}$ \\
\hline Subcutaneous WAT & Human & $\alpha 7$ & qPCR & Gene expression of $\alpha 7 \mathrm{nAChR}$ is reduced in obese subjects & $\begin{array}{l}\text { Cancello et al. } \\
\text { (2012) }\end{array}$ \\
\hline $\begin{array}{l}\text { Isolated mature } \\
\text { adipocyte }\end{array}$ & Human & $\alpha 7$ & $\mathrm{qPCR} / \mathrm{WB}$ & $\begin{array}{l}\alpha 7 \mathrm{nAChR} \text { expression is higher in mature adipocytes than in } \\
\text { whole adipose tissue. } \alpha 7 \mathrm{nAChR} \text { in adipocytes of obese } \\
\text { subjects is significantly lowered (mRNA and protein). In } \\
\text { obese subjects, weight loss increases } \alpha 7 \mathrm{nAChR} \text { expression }\end{array}$ & $\begin{array}{l}\text { Cancello et al. } \\
\text { (2012) }\end{array}$ \\
\hline Epididymal WAT & Mice & $\alpha 7$ & $\mathrm{qPCR}$ & $\begin{array}{l}\text { The expression of } \alpha 7 \mathrm{nAChR} \text { tends to be higher in adipose } \\
\text { macrophages than in isolated adipocytes. } \\
\text { Butyrylcholinesterase is the major cholinesterase in adipose } \\
\text { tissue (up-regulated with chronic nicotine treatment, down- } \\
\text { regulated in DIO and in } \mathrm{db} / \mathrm{db} \text { mice) }\end{array}$ & $\begin{array}{l}\text { Wang et al. } \\
\quad(2011)\end{array}$ \\
\hline $\begin{array}{l}\text { In vitro } \\
\text { differentiated } \\
\text { adipocyte }\end{array}$ & Rat & $\begin{array}{l}\alpha 1-7,9,10, \beta 1-4 \\
\quad \delta, \varepsilon\end{array}$ & $\mathrm{PCR} / \mathrm{IHC}$ & $\begin{array}{l}\text { Functionality of nAChRs expression is also substantiated by a } \\
\text { dose-dependent binding of labeled nicotine }\end{array}$ & Liu et al. (2004) \\
\hline \multicolumn{6}{|l|}{ Pancreatic islet cell } \\
\hline Islet $(\beta$ cell) & Rat & $\alpha 7$ & $\mathrm{IHC}$ & $\begin{array}{l}\alpha 7 \mathrm{nAChR} \text { subunit is expressed in the central part of the islets } \\
\text { and co-localizes with insulin, ChAT, VAChT while AChE } \\
\text { expression is stronger in the surrounding, exocrine tissue } \\
\text { and in the mantle region of the islet }\end{array}$ & Delbro (2012) \\
\hline INS-1 ( $\beta$ cell line $)$ & Rat & $\begin{array}{l}\alpha 2, \alpha 3, \alpha 4, \alpha 5, \alpha 7 \\
\quad \beta 2\end{array}$ & PCR & $\begin{array}{l}\text { Binding of } \alpha \text {-bungarotoxin and cytisine indicates functionality } \\
\text { of these subunits in INS- } 1 \text { cells and rat islets }\end{array}$ & $\begin{array}{l}\text { Yoshikawa et al. } \\
\text { (2005) }\end{array}$ \\
\hline $\begin{array}{l}\text { TC6 insulinoma } \\
\text { cells ( } \beta \text { cell line })\end{array}$ & Mice & $\alpha 3, \alpha 4, \beta 2, \beta 4$ & PCR & $\begin{array}{l}\alpha 5 \mathrm{nAChR} \text { subunit mRNA is also detected, whereas mRNAs } \\
\text { for } \alpha 2, \alpha 6 \text {, and } \alpha 7 \mathrm{nAChR} \text { subunits are not detected. } \\
\text { Nicotinic agonists (epibatidine }>\text { nicotine } \approx \text { cytisine, } \\
\text { A- } 83850 \text {, and DMPP) also elicit increases in intracellular } \\
\text { calcium. Binding results with }\left[{ }^{3} \mathrm{H}\right] \text { epibatidine demonstrate } \\
\text { high levels of nicotinic receptors with high affinity }\end{array}$ & $\begin{array}{l}\text { Ohtani et al. } \\
\text { (2006) }\end{array}$ \\
\hline
\end{tabular}

Adipo $Q$ adiponectin, Cox2 cyclooxygenase-2, DMPP dimethylphenylpiperazinium

et al. 2007); (3) decreased physical activity [linked to alterations in motor behavior related to disruptions in the mesoaccumbens dopaminergic pathway (Oliff and Gallardo 1999)]; and (4) decreased cold-induced thermogenesis [in accordance with alterations in adrenergic responsiveness of sympathetic target tissues (Navarro et al. 1990) and blunted sympathetic responsiveness leading to hypoactivity of the noradrenergic system (Levin 2005)].

\section{Nicotinic Cholinergic Signaling in Pancreatic Islet Biology and Therapeutic Perspectives in the Treatment of Diabetes}

Pancreatic islets (also named Langerhans islets) are clusters of endocrine cells which represent approximately $1-2 \%$ of the mass of the whole pancreatic tissue. These endocrine structures play a central role in metabolism through direct secretion into the blood flow of key hormones involved in the regulation of nutrient uptake or transformation. $\beta$ Cells (producing insulin, c-peptide and amylin) and $\alpha$ cells (producing glucagon) are the major cell types present in pancreatic islets; other cell types include $\delta$ cells (producing somatostatin), PP cells (producing pancreatic polypeptide) and $\varepsilon$ cells (producing ghrelin). In addition to nutritional, hormonal and paracrine regulatory mechanisms, the secretory activity of pancreatic islets is under tight control of the autonomic nervous system involving cholinergic signaling, as demonstrated by the tenfold higher activity of CHAT and AChE in the islets compared to the surrounding exocrine tissue (Godfrey and Matschinsky 1975). At the sympathetic level, the preganglionic fibers release ACh that acts on nicotinic receptors on intraganglionic neurons, whereas the postganglionic fibers release several neurotransmitters including norepinephrine (Ahren 2000; Cerf 2011; Gilon and Henquin 2001; Woods and Porte 1974). Sympathetic islet innervation lowers insulin and stimulates glucagon release to maintain or increase glycemia in stress conditions such as neuroglycopenia or physical exercise (Ahren 2000; Cerf 2011; Gilon and Henquin 2001; Woods and Porte 1974). At the parasympathetic level, the preganglionic fibers reach 
intrapancreatic ganglia dispersed in the exocrine tissue and unmyelinated postganglionic fibers leave the ganglia toward the islets (Ahren 2000; Cerf 2011; Gilon and Henquin 2001; Woods and Porte 1974). Preganglionic vagal fibers release $\mathrm{ACh}$ that binds to nicotinic receptors on intraganglionic neurons and postganglionic vagal fibers release several neurotransmitters including ACh. Parasympathetic islet innervation stimulates insulin, glucagon and PP release (Ahren 2000; Cerf 2011; Gilon and Henquin 2001; Woods and Porte 1974).

The muscarinic receptor is classically described as the terminal effector of cholinergic signaling in pancreatic $\beta$ cells (Gilon and Henquin 2001; Lundquist 1982; Ruiz de Azua et al. 2012), and the function of nicotinic cholinergic receptors in the context of pancreatic islets has long been limited to their role in ganglionic autonomic neurotransmission. Nicotinic cholinergic signaling stimulates vagal transmission in ganglionic neurons, and $\mathrm{nAChR}$ agonists, including nicotine, mimic this vagal signaling (Ahren et al. 1986; Ahren and Taborsky 1986; Kirchgessner and Liu 1998; Nishi et al. 1987; Sha et al. 1997; Stagner and Samols 1986).

More recent direct detection of $\mathrm{nAChRs}$ in immune and islet cells leads to revise the potential role of the nicotinic cholinergic pathway in endocrine pancreas physiology and diseases. Species differences in morphological organization of pancreatic islets need to be considered in this context. In contrast to rodent islets, harboring a central core of $\beta$ cells surrounded by peripheral $\alpha$ cells in the mantle position, the cytoarchitecture of human islets does not show such distinct anatomical subdivisions with $\alpha, \beta$ and $\delta$ cells scattered throughout the islet, complicating a precise order of paracrine interactions (Cabrera et al. 2006). The innervation pattern of islets also seems to be different between rodents and humans. Visualization of axons in three dimensions and quantification of axonal densities and contacts within pancreatic islets show that human endocrine cells are sparsely contacted by autonomic axons (Rodriguez-Diaz et al. 2011a). Few parasympathetic cholinergic axons penetrate the human islet, and the invading sympathetic fibers preferentially innervate smooth muscle cells of blood vessels located within the islet, suggesting a role in the control of local blood flow (Rodriguez-Diaz et al. 2011a). Poor cholinergic innervation of human islets appears to be substituted by the $\alpha$ cells which provide paracrine cholinergic input to surrounding endocrine cells (Rodriguez-Diaz et al. 2011b). ACh secretion by $\alpha$ cells seems to sensitize the $\beta$ cell response to increase in glucose concentration (Rodriguez-Diaz et al. 2011b), making the paracrine cholinergic signaling within islets a potential therapeutic target in diabetes. In rodents, the expression of ChAT, VAChT, CHT-1 and $\alpha 7$ nAChR is identified in the core of islets ( $\beta$ cells), and expression of AChE is stronger in the surrounding exocrine tissue and in the mantle region of the islet (Delbro 2012), suggesting that rat $\beta$ cells produce ACh which could in an autocrine/paracrine mechanism participate in insulin secretion via $\alpha 7 \mathrm{nAChR}$ receptors. Some previous functional experiments substantiate this histologically based hypothesis and attribute a primary role to nicotinic cholinergic signaling in pancreatic islet secretion. In islets isolated from rats, exposure to the muscarinic receptor blocker, atropine, suppresses insulin release, whereas $\alpha$-bungarotoxin (antagonist of the $\alpha 7$ $\mathrm{nAChR}$ ) increases insulin and glucagon release (Ejiri et al. 1989, 1990), suggesting that not only muscarinic but also nicotinic cholinergic receptors influence insulin release in isolated islets. In rat and human islets, nicotine moderately inhibits insulin release, both in the presence of basal and elevated glucose levels (Yoshikawa et al. 2005). Specific binding of labeled nicotine is demonstrated in rat islets as well as in INS-1, a rat $\beta$ cell line expressing $\alpha 2, \alpha 3, \alpha 4, \alpha 5$, $\alpha 7$ and $\beta 2$ nAChR subunits (Yoshikawa et al. 2005). Cytisine (a partial agonist of $\alpha 4 / \beta 2 *$ nAChRs and a full agonist of $\alpha 3 / \beta 4 *$ nAChRs) partially inhibits tolbutamideinduced insulin release (by direct closure of $\mathrm{K}^{+}$-ATP channels) in INS-1 cells (Yoshikawa et al. 2005). In contrast, specific binding of $\alpha$-bungarotoxin slightly increases insulin release in INS-1 cells (Yoshikawa et al. 2005). In mice $\beta$-TC6 insulinoma cells harboring $\alpha 3, \alpha 4, \beta 2, \beta 4$ nAChR subunits, nicotine elicits membrane depolarization, elevation of intracellular calcium and release of insulin (Ohtani et al. 2006). In these $\beta$-TC6 insulinoma cells, the maximal elevation of cytoplasmic $\left[\mathrm{Ca}^{2+}\right]$ induced by carbamylcholine (a mixed muscarinic/nicotinic receptor agonist) is greater than that of oxotremorine $\mathrm{M}$ (a selective muscarinic agonist) or nicotine alone (Ohtani et al. 2009). Nevertheless, carbamylcholine induces a smaller extent of insulin secretion than oxotremorine $\mathrm{M}$, suggesting a negative type of interaction between nicotinic and muscarinic cholinergic receptors (Ohtani et al. 2009). Together, these observations suggest the presence of a functional nicotinic cholinergic system in isolated rodent and human pancreatic islets, as well as in available endocrine $\beta$ cell lines (Table 2). In contrast to muscarinic cholinergic signaling, nicotinic cholinergic signaling in islets seems rather to dampen insulin secretion through presently unknown mechanisms. Nevertheless, several studies have successfully investigated the therapeutic perspectives proposed by nicotinic cholinergic pathways in the pathological context of diabetes.

\section{Type 1 Diabetes}

Type 1 diabetes (T1D) is a juvenile disease due to immune destruction of the insulin-producing pancreatic $\beta$ cells (Noorchashm et al. 1997). Experimentally, rodent models 
of the disease range from animals with spontaneously developing autoimmune diabetes (NOD mice, BB rats) to chemical ablation of the pancreatic beta cells (with streptozotocin or alloxan) (King 2012).

In vitro, stimulation of the muscarinic receptor by carbachol protects islets from the apoptotic/necrotic action of cytokines characteristic of T1D (Laychock et al. 2006). Interestingly, nicotinic cholinergic signaling could also present protective effects. In fact, nicotine administration reduces hyperglycemia and preserves pancreatic insulin content, reducing the incidence of T1D in both streptozotocin-treated and NOD mice (Mabley et al. 2002). Mechanistically, the elevated levels of pro-inflammatory cytokines (IL-12, IL-1, TNF- $\alpha$, and interferon $\gamma$ ) are downregulated in pancreas of both diabetic models by nicotine administration (Mabley et al. 2002). In contrast, nicotine increases the pancreatic levels of anti-inflammatory cytokines (IL-4 and IL-10), suggesting that nicotinic cholinergic signaling reduces the incidence of T1D in rodent models by shifting the profile of pancreatic cytokine expression from helper $\mathrm{T}$ cells type1 to type2 (Mabley et al. 2002).

\section{Type 2 Diabetes}

Type 2 diabetes (T2D also known as noninsulin-dependent diabetes or adult-onset diabetes) is primarily due to increased peripheral insulin resistance which challenges the capacity of the $\beta$ cells to produce a compensative amount of insulin. The pathology is generally linked to increased fat mass and animal models mimicking the disease involve for example genetic mutation in leptin gene (ob/ob mice), in leptin receptor gene ( $\mathrm{db} / \mathrm{db}$ mice or Zucker fatty rats) or diet-induced obesity (DIO) (King 2012).

Clinically, a genetic study involving multiple SNP analysis reveals significant associations between variants in the $\alpha 5 / \alpha 3 / \beta 4 \mathrm{nAChR}$ gene cluster with both insulin resistance and T2D (Yang et al. 2012). In control rats, nicotine administration reduces insulinemia and globally improves insulin sensitivity (Xu et al. 2012). In Zucker fatty rats chronically exposed to nicotine, both basal and post-glucose tolerance test glycaemia are reduced (Liu et al. 2001). In this model, nicotine administration reduces pancreatic islet size (without change in $\alpha / \beta$ cell mass proportion) (Liu et al. 2001). Further investigations reveal that chronic nicotine treatment in Zucker fatty rats does not impact body weight and food intake, but improves insulin sensitivity in link with a liver-specific attenuation of glycogenogenesis and gluconeogenesis (Liu et al. 2003). In $\mathrm{db} / \mathrm{db}$ and in DIO mice, nicotine administration improves glucose homeostasis and insulin sensitivity also independently of any change in body weight (Wang et al. 2011), but in connection with an $\alpha 7 \mathrm{nAChR}$ role on glucose metabolism. $\alpha 7 \mathrm{nAChR}^{-1-}$ mice are gluco-intolerant and resistant to insulin without change in body weight or insulin secretion (Wang et al. 2011). Likewise, nicotineinduced insulin-sensitizing action is abrogated in $\alpha 7$ $\mathrm{nAChR}^{-1-}$ mice (Xu et al. 2012). $\alpha 7 \mathrm{nAChR}$ deficiency seems to elevate adipose tissue infiltration by classically activated macrophages and leads to an inflammatory-prone status which induces insulin resistance. In contrast, pharmacological administration of the $\alpha 7 \mathrm{nAChR}$ agonist TC7020 to $\mathrm{db} / \mathrm{db}$ obese mice reduces their elevated glucose levels and lowers their elevated plasma levels of triglycerides and TNF- $\alpha$ (Marrero et al. 2010). These benefits are abolished by both the $\alpha 7$-selective antagonist methyllycaconitine and a Janus kinase 2 inhibitor, confirming the involvement of $\alpha 7 \mathrm{nAChRs}$ and the downstream JAK2/ STAT3 signaling pathway (Marrero et al. 2010). Chronic treatment with the selective $\alpha 7 \mathrm{nAChR}$ agonist PNU282987 significantly enhances insulin sensitivity in normal mice as well as in insulin-resistant AMP-activated kinase$\alpha 2^{-/-}$mice, also in link with enhanced phosphorylation of STAT3 (Xu et al. 2012).

Together, these preclinical observations in animals suggest that peripheral nicotinic cholinergic signaling could represent a potential therapeutic target for the different forms of diabetes (Table 1).

\section{Early Deleterious Programming Action}

In contrast to the insulin-sensitizing and anti-inflammatory action of nicotinic cholinergic signaling previously discussed, fetal nicotinic oversignaling seems to present a deleterious action in programming altered glucose homeostasis later in life. Recent data suggest that insulin resistance and T2D could be "programmed" during intrauterine life by diverse insults to the growing fetus (Berends and Ozanne 2012), including exposure to endocrine disruptors (Alonso-Magdalena et al. 2011). In this context, developing fetuses can be widely exposed to tobacco and nicotine (Althabe et al. 2008; Martin et al. 2005; Nabet et al. 2005) and epidemiological studies have demonstrated an increased prevalence of diabetes in children born to smoking women (Montgomery and Ekbom 2002). This clinical observation is corroborated by several animal studies investigating the impact of early life exposure to nicotine on endocrine pancreas development and later control of glucose homeostasis. $\alpha 2-\alpha 4, \alpha 6, \alpha 7$ and $\beta 2-\beta 4$ nAChR subunits can be detected early in the developing rat pancreas (Bruin et al. 2008b), suggesting a primary deleterious effect of prenatal nicotine exposure on the development of this organ. Rat offspring exposed to nicotine during fetal and neonatal life present increased $\beta$ cell apoptosis at birth (Holloway et al. 2005) and reduced $\beta$ cell mass in adulthood, indicating a permanent $\beta$ cell loss 
(Bruin et al. 2007). Islet size, number and transcriptional activity are reduced on postnatal day 7 due to prenatal nicotine exposure in rats (Somm et al. 2008). Underlying molecular mechanisms involved in nicotine-induced $\beta$ cell apoptosis during development include (1) the death receptor pathway [with elevated Fas and soluble FasL levels (Bruin et al. 2008a)], (2) the mitochondrial pathway [with increases in the ratio of $\mathrm{Bcl} 2 / \mathrm{Bax}$, Bax translocation to the mitochondria and cytochrome $c$ release to the cytosol (Bruin et al. 2008a)], (3) oxidative stress [with increased pancreatic glutathione peroxidase and manganese superoxide dismutase protein expression consecutive to induction of reactive oxygen species production (Bruin et al. 2008b)]. These early morphological and molecular alterations lead to later defect in control of glucose homeostasis. Animal models exposed early to nicotine show glucose intolerance (Holloway et al. 2005; Somm et al. 2008) associated with insulin resistance (Somm et al. 2008). Impairment in glucose homeostasis caused by perinatal nicotine exposure also seems to be transgenerational (Holloway et al. 2007), suggesting nicotine-induced epigenetic modifications persisting throughout generations.

\section{Conclusion}

nAChRs represent a large and complex family of ligandgated ion channels that are widely expressed in the synapse of the central and peripheral nervous system and the neuromuscular junction. More recently, new functions in intracellular signaling and detection in the peripheral nonneuronal cell have renewed the interest for this class of receptors in various fields of investigation.

In the present review, we focus our attention on the role of nAChRs in adipose tissues and pancreatic islet biology, as well as on the potential therapeutic perspectives for nicotinic cholinergic signaling through these nAChRs in metabolic diseases such as obesity and diabetes. In fact, various $\mathrm{nAChR}$ subunits are expressed in pancreatic islet cells, adipocytes and, also importantly, in immune cells interacting with them. Independently of its well-known central anorexigenic action, experimental exposure to nicotine or other $\mathrm{nAChR}$ agonists activates lipolytic activity in WAT and thermogenic activity in BAT through both nervous and non-nervous mechanisms. Moreover, moderate doses of nicotine seem to be effective in reducing the inflammation process linked to obesity. These actions allow dampening metabolic defects in various rodent models of genetic and nutritional obesity. Anti-inflammatory and insulin-sensitizing properties of the nicotinic cholinergic signaling pathway also show therapeutic benefit for the treatment of T1D and T2D in preclinical studies. Metabolic phenotyping of mice deficient in some nAChR subunits (in particular, $\alpha 7 \mathrm{nAChR}$ ) confirms this rationale considering nicotinic cholinergic signaling as a treatment for metabolic syndrome. Keeping in view that nicotine stimulates non-specifically all types of nAChRs, leading to toxic effects at high doses, and that the $\alpha 7 \mathrm{nAChR}$ seems to be the subtype most involved in inflammation and insulin sensitivity improvement, development and testing of new specific $\alpha 7 \mathrm{nAChR}$ agonists represent a rather promising new pharmacotherapeutic approach.

In contrast to potential therapeutic use in metabolic diseases, an overstimulation of this signaling pathway during the early stage of development (typically through nicotine exposure during fetal life) presents deleterious consequences in the ontogeny and functionality of adipose tissue and the endocrine pancreas which persist throughout life.

Acknowledgments This work was supported by the University of Geneva, School of Medicine. The author also wishes to extend special thanks to Audrey Toulotte for manuscript language correction.

Conflict of interest The author has nothing to disclose.

\section{References}

Ahren B (2000) Autonomic regulation of islet hormone secretionimplications for health and disease. Diabetologia 43:393-410

Ahren B, Taborsky GJ Jr (1986) The mechanism of vagal nerve stimulation of glucagon and insulin secretion in the dog. Endocrinology 118:1551-1557

Ahren B, Paquette TL, Taborsky GJ Jr (1986) Effect and mechanism of vagal nerve stimulation on somatostatin secretion in dogs. Am J Physiol 250(2 Pt 1):E212-E217

Al Mamun A, Lawlor DA, Alati R et al (2006) Does maternal smoking during pregnancy have a direct effect on future offspring obesity? Evidence from a prospective birth cohort study. Am J Epidemiol 164:317-325

Albuquerque EX, Santos MD, Alkondon M et al (2001) Modulation of nicotinic receptor activity in the central nervous system: a novel approach to the treatment of Alzheimer disease. Alzheimer Dis Assoc Disord 15(Suppl 1):S19-S25

Albuquerque EX, Pereira EF, Alkondon M et al (2009) Mammalian nicotinic acetylcholine receptors: from structure to function. Physiol Rev 89:73-120

Alonso-Magdalena P, Quesada I, Nadal A (2011) Endocrine disruptors in the etiology of type 2 diabetes mellitus. Nat Rev Endocrinol 7:346-353

Althabe F, Colomar M, Gibbons L et al (2008) Smoking during pregnancy in Argentina and Uruguay. Medicina 68:48-54

Amoruso A, Bardelli C, Gunella G et al (2007) Quantification of PPAR-gamma protein in monocyte/macrophages from healthy smokers and non-smokers: a possible direct effect of nicotine. Life Sci 81:906-915

An Z, Wang H, Song P et al (2007) Nicotine-induced activation of AMP-activated protein kinase inhibits fatty acid synthase in 3T3L1 adipocytes: a role for oxidant stress. J Biol Chem 282:26793-26801

Andersson K, Arner P (1995) Cholinoceptor-mediated effects on glycerol output from human adipose tissue using in situ microdialysis. Br J Pharmacol 115:1155-1162 
Andersson K, Arner P (2001) Systemic nicotine stimulates human adipose tissue lipolysis through local cholinergic and catecholaminergic receptors. Int $\mathrm{J}$ Obes Relat Metab Disord 25:1225-1232

Arai K, Kim K, Kaneko K et al (2001) Nicotine infusion alters leptin and uncoupling protein $1 \mathrm{mRNA}$ expression in adipose tissues of rats. Am J Physiol Endocrinol Metab 280:E867-E876

Baba S, Tatsumi M, Ishimori $\mathrm{T}$ et al (2007) Effect of nicotine and ephedrine on the accumulation of ${ }^{18}$ F-FDG in brown adipose tissue. J Nucl Med 48:981-986

Batt RA, Topping DL (1979) Acute effects of nicotine on plasma free fatty acid concentrations and on the response to cold stress, in lean and obese (genotype ob/ob) mice. Int J Obes 3:7-13

Berends LM, Ozanne SE (2012) Early determinants of type-2 diabetes. Best Pract Res Clin Endocrinol Metab 26:569-580

Bishop C, Parker GC, Coscina DV (2004) Systemic nicotine alters whole-body fat utilization in female rats. Physiol Behav 80:563-567

Borgerding M, Klus H (2005) Analysis of complex mixturescigarette smoke. Exp Toxicol Pathol 57(Suppl 1):43-73

Brees DJ, Elwell MR, Tingley FD 3rd et al (2008) Pharmacological effects of nicotine on norepinephrine metabolism in rat brown adipose tissue: relevance to nicotinic therapies for smoking cessation. Toxicol Pathol 36:568-575

Brindis RG, Petersen BJ, Thompson JH et al (1973) Lack of effect of chronic nicotine administration on fatty acid distribution in the liver, testis, and adipose tissue of male Fischer-344 rats. J Lipid Res 14:688-691

Bruin JE, Kellenberger LD, Gerstein HC et al (2007) Fetal and neonatal nicotine exposure and postnatal glucose homeostasis: identifying critical windows of exposure. $\mathrm{J}$ Endocrinol 194:171-178

Bruin JE, Gerstein HC, Morrison KM et al (2008a) Increased pancreatic beta-cell apoptosis following fetal and neonatal exposure to nicotine is mediated via the mitochondria. Toxicol Sci 103:362-370

Bruin JE, Petre MA, Lehman MA et al (2008b) Maternal nicotine exposure increases oxidative stress in the offspring. Free Radic Biol Med 44:1919-1925

Brunzell DH, Russell DS, Picciotto MR (2003) In vivo nicotine treatment regulates mesocorticolimbic CREB and ERK signaling in C57B1/6 J mice. J Neurochem 84:1431-1441

Cabrera O, Berman DM, Kenyon NS et al (2006) The unique cytoarchitecture of human pancreatic islets has implications for islet cell function. Proc Natl Acad Sci USA 103:2334-2339

Cancello R, Zulian A, Maestrini S et al (2012) The nicotinic acetylcholine receptor alpha7 in subcutaneous mature adipocytes: downregulation in human obesity and modulation by dietinduced weight loss. Int J Obes 36:1552-1557

Cerf ME (2011) Islet organogenesis, angiogenesis and innervation. Cell Biol Int 35:1065-1078

Chajek-Shaul T, Friedman G, Dabach Y et al (1987) The effect of acute and chronic administration of nicotine on lipoprotein lipase activity. Int Angiol 6:29-36

Changeux JP (1990) The TiPS lecture. The nicotinic acetylcholine receptor: an allosteric protein prototype of ligand-gated ion channels. Trends Pharmacol Sci 11:485-492

Changeux JP (2012) The nicotinic acetylcholine receptor: the founding father of the pentameric ligand-gated ion channel superfamily. J Biol Chem 287:40207-40215

Changeux JP, Kasai M, Huchet M et al (1970) Extraction from electric tissue of gymnotus of a protein presenting several typical properties characteristic of the physiological receptor of acetylcholine. C R Acad Sci Hebd Seances Acad Sci D 270:2864-2867

Cinti S (2005) The adipose organ. Prostaglandins Leukot Essent Fatty Acids 73:9-15
Cinti S (2012) The adipose organ at a glance. Dis Mod Mech 5:588-594

Conti-Fine BM, Navaneetham D, Lei S et al (2000) Neuronal nicotinic receptors in non-neuronal cells: new mediators of tobacco toxicity? Eur J Pharmacol 393:279-294

Cypess AM, Lehman S, Williams G et al (2009) Identification and importance of brown adipose tissue in adult humans. N Engl J Med 360:1509-1517

Dajas-Bailador FA, Soliakov L, Wonnacott S (2002) Nicotine activates the extracellular signal-regulated kinase $1 / 2$ via the alpha7 nicotinic acetylcholine receptor and protein kinase A, in SH-SY5Y cells and hippocampal neurons. J Neurochem 80:520-530

de Jonge WJ, van der Zanden EP, The FO et al (2005) Stimulation of the vagus nerve attenuates macrophage activation by activating the Jak2-STAT3 signaling pathway. Nat Immunol 6:844-851

de Oliveira E, Moura EG, Santos-Silva AP et al (2010) Neonatal nicotine exposure causes insulin and leptin resistance and inhibits hypothalamic leptin signaling in adult rat offspring. J Endocrinol 206:55-63

Delbro DS (2012) Expression of the non-neuronal cholinergic system in rat beta-cells. Auton Neurosci 167:75-77

Eglen RM (2012) Overview of muscarinic receptor subtypes. Hand Exp Pharmacol 208:3-28

Ejiri K, Taniguchi H, Baba S (1989) Participation of nicotinic receptor in hormone release from isolated rat islets of Langerhans. Diabetes Res Clin Pract 6:53-59

Ejiri K, Taniguchi GH, Ishihara K et al (1990) Possible involvement of cholinergic nicotinic receptor in insulin release from isolated rat islets. Diabetes Res Clin Pract 8:193-199

Eliasson B, Smith U, Lonnroth P (1997) No acute effects of smoking and nicotine nasal spray on lipolysis measured by subcutaneous microdialysis. Eur J Clin Investig 27:503-509

Frontini A, Cinti S (2010) Distribution and development of brown adipocytes in the murine and human adipose organ. Cell Metab 11:253-256

Fu Y, Matta SG, Brower VG et al (2001) Norepinephrine secretion in the hypothalamic paraventricular nucleus of rats during unlimited access to self-administered nicotine: an in vivo microdialysis study. J Neurosci 21:8979-8989

Gahring LC, Rogers SW (2005) Neuronal nicotinic acetylcholine receptor expression and function on nonneuronal cells. AAPS J 7:E885-E894

Gao YJ, Holloway AC, Zeng ZH et al (2005) Prenatal exposure to nicotine causes postnatal obesity and altered perivascular adipose tissue function. Obes Res 13:687-692

Gergalova G, Lykhmus O, Kalashnyk O et al (2012) Mitochondria express alpha7 nicotinic acetylcholine receptors to regulate $\mathrm{Ca}^{2+}$ accumulation and cytochrome $c$ release: study on isolated mitochondria. PLoS ONE 7:e31361

Gilon P, Henquin JC (2001) Mechanisms and physiological significance of the cholinergic control of pancreatic beta-cell function. Endocr Rev 22:565-604

Gluckman PD, Hanson MA (2004) The developmental origins of the metabolic syndrome. Trends Endocrinol Metab 15:183-187

Gochberg-Sarver A, Kedmi M, Gana-Weisz M et al (2012) Tnfalpha, Cox 2 and AdipoQ adipokine gene expression levels are modulated in murine adipose tissues by both nicotine and nACh receptors containing the beta2 subunit. Mol Genet Metab 107:561-570

Godfrey DA, Matschinsky FM (1975) Enzymes of the cholinergic system in islets of Langerhans. J Histochem Cytochem 23:645-651

Hakansson ML, Meister B (1998) Transcription factor STAT3 in leptin target neurons of the rat hypothalamus. Neuroendocrinology 68:420-427 
Hales CN, Barker DJ (1992) Type 2 (non-insulin-dependent) diabetes mellitus: the thrifty phenotype hypothesis. Diabetologia 35:595-601

Harwood HJ Jr (2012) The adipocyte as an endocrine organ in the regulation of metabolic homeostasis. Neuropharmacology 63:57-75

Hogg RC, Raggenbass M, Bertrand D (2003) Nicotinic acetylcholine receptors: from structure to brain function. Rev Physiol Biochem Pharmacol 147:1-46

Holloway AC, Lim GE, Petrik JJ et al (2005) Fetal and neonatal exposure to nicotine in Wistar rats results in increased beta cell apoptosis at birth and postnatal endocrine and metabolic changes associated with type 2 diabetes. Diabetologia 48:2661-2666

Holloway AC, Cuu DQ, Morrison KM et al (2007) Transgenerational effects of fetal and neonatal exposure to nicotine. Endocrine 31:254-259

Huang H, Xu Y, van den Pol AN (2011) Nicotine excites hypothalamic arcuate anorexigenic proopiomelanocortin neurons and orexigenic neuropeptide Y neurons: similarities and differences. J Neurophysiol 106:1191-1202

Huang X, Cheng Z, Su Q et al (2012) Neuroprotection by nicotine against colchicine-induced apoptosis is mediated by PI3-kinaseAkt pathways. Int J Neurosci 122:324-332

Hucho F, Changeux JP (1973) Molecular weight and quaternary structure of the cholinergic receptor protein extracted by detergents from Electrophorus electricus electric tissue. FEBS Lett 38:11-15

Hurst R, Rollema H, Bertrand D (2013) Nicotinic acetylcholine receptors: from basic science to therapeutics. Pharmacol Ther $137: 22-54$

Ishii M, Kurachi Y (2006) Muscarinic acetylcholine receptors. Curr Pharm Des 12:3573-3581

Jang MH, Shin MC, Kim KH et al (2003) Nicotine administration decreases neuropeptide $\mathrm{Y}$ expression and increases leptin receptor expression in the hypothalamus of food-deprived rats. Brain Res 964:311-315

Jo YH, Talmage DA, Role LW (2002) Nicotinic receptor-mediated effects on appetite and food intake. J Neurobiol 53:618-632

Jo YH, Wiedl D, Role LW (2005) Cholinergic modulation of appetite-related synapses in mouse lateral hypothalamic slice. J Neurosci 25:11133-11144

Kane JK, Parker SL, Matta SG et al (2000) Nicotine up-regulates expression of orexin and its receptors in rat brain. Endocrinology 141:3623-3629

Kane JK, Parker SL, Li MD (2001) Hypothalamic orexin-A binding sites are downregulated by chronic nicotine treatment in the rat. Neurosci Lett 298:1-4

Kihara T, Shimohama S, Sawada H et al (2001) Alpha 7 nicotinic receptor transduces signals to phosphatidylinositol 3-kinase to block A beta-amyloid-induced neurotoxicity. J Biol Chem 276:13541-13546

Kim J (2008) Association of CHRNA2 polymorphisms with overweight/obesity and clinical characteristics in a Korean population. Clin Chem Lab Med 46:1085-1089

King AJ (2012) The use of animal models in diabetes research. Br J Pharmacol 166:877-894

Kirchgessner AL, Liu MT (1998) Immunohistochemical localization of nicotinic acetylcholine receptors in the guinea pig bowel and pancreas. J Comp Neurol 390:497-514

Kloek C, Haq AK, Dunn SL et al (2002) Regulation of Jak kinases by intracellular leptin receptor sequences. $\mathrm{J}$ Biol Chem 277:41547-41555

Koupil I, Toivanen P (2008) Social and early-life determinants of overweight and obesity in 18-year-old Swedish men. Int J Obes $32: 73-81$
Lakhan SE, Kirchgessner A (2011) Anti-inflammatory effects of nicotine in obesity and ulcerative colitis. J Transl Med 9:129

Laychock SG, Sessanna SM, Lin MH et al (2006) Sphingosine 1-phosphate affects cytokine-induced apoptosis in rat pancreatic islet beta-cells. Endocrinology 147:4705-4712

Le Novere N, Changeux JP (1995) Molecular evolution of the nicotinic acetylcholine receptor: an example of multigene family in excitable cells. J Mol Evol 40:155-172

Levin ED (2005) Fetal nicotinic overload, blunted sympathetic responsivity, and obesity. Birth Defects Res A Clin Mol Teratol 73:481-484

Li MD, Kane JK (2003) Effect of nicotine on the expression of leptin and forebrain leptin receptors in the rat. Brain Res 991:222-231

Li MD, Kane JK, Parker SL et al (2000a) Nicotine administration enhances NPY expression in the rat hypothalamus. Brain Res 867:157-164

Li MD, Parker SL, Kane JK (2000b) Regulation of feeding-associated peptides and receptors by nicotine. Mol Neurobiol 22:143-165

Lindstrom J (1996) Neuronal nicotinic acetylcholine receptors. Ion Channels 4:377-450

Liu RH, Kurose T, Matsukura S (2001) Oral nicotine administration decreases tumor necrosis factor-alpha expression in fat tissues in obese rats. Metabolism 50:79-85

Liu RH, Mizuta M, Matsukura S (2003) Long-term oral nicotine administration reduces insulin resistance in obese rats. Eur J Pharmacol 458:227-234

Liu RH, Mizuta M, Matsukura S (2004) The expression and functional role of nicotinic acetylcholine receptors in rat adipocytes. J Pharmacol Exp Ther 310:52-58

Lowell BB, Spiegelman BM (2000) Towards a molecular understanding of adaptive thermogenesis. Nature 404:652-660

Lundquist I (1982) Cholinergic muscarinic effects on insulin release in mice. Pharmacology 25:338-347

Lupien JR, Bray GA (1988) Nicotine increases thermogenesis in brown adipose tissue in rats. Pharmacol Biochem Behav 29:33-37

Mabley JG, Pacher P, Southan GJ et al (2002) Nicotine reduces the incidence of type I diabetes in mice. J Pharmacol Exp Ther 300:876-881

Mano-Otagiri A, Iwasaki-Sekino A, Ohata $\mathrm{H}$ et al (2009) Nicotine suppresses energy storage through activation of sympathetic outflow to brown adipose tissue via corticotropin-releasing factor type 1 receptor. Neurosci Lett 455:26-29

Marrero MB, Lucas R, Salet C et al (2010) An alpha7 nicotinic acetylcholine receptor-selective agonist reduces weight gain and metabolic changes in a mouse model of diabetes. J Pharmacol Exp Ther 332:173-180

Martin JA, Hamilton BE, Sutton PD et al (2005) Births: final data for 2003. Natl Vital Stat Rep 54:1-116

Martinez de Morentin PB, Whittle AJ, Ferno J et al (2012) Nicotine induces negative energy balance through hypothalamic AMPactivated protein kinase. Diabetes 61:807-817

Meguid MM, Fetissov SO, Varma M et al (2000) Hypothalamic dopamine and serotonin in the regulation of food intake. Nutrition 16:843-857

Meyer EL, Gahring LC, Rogers SW (2002) Nicotine preconditioning antagonizes activity-dependent caspase proteolysis of a glutamate receptor. J Biol Chem 277:10869-10875

Minana MD, Montoliu C, Llansola M et al (1998) Nicotine prevents glutamate-induced proteolysis of the microtubule-associated protein MAP-2 and glutamate neurotoxicity in primary cultures of cerebellar neurons. Neuropharmacology 37:847-857

Mineur YS, Abizaid A, Rao Y et al (2011) Nicotine decreases food intake through activation of POMC neurons. Science 332:1330-1332 
Mizutani T, Suzuki K, Kondo N et al (2007) Association of maternal lifestyles including smoking during pregnancy with childhood obesity. Obesity 15:3133-3139

Montgomery SM, Ekbom A (2002) Smoking during pregnancy and diabetes mellitus in a British longitudinal birth cohort. BMJ 324:26-27

Nabet C, Ancel PY, Burguet A et al (2005) Smoking during pregnancy and preterm birth according to obstetric history: French national perinatal surveys. Paediatr Perinat Epidemiol 19:88-96

Nakayama H, Numakawa T, Ikeuchi T (2002) Nicotine-induced phosphorylation of Akt through epidermal growth factor receptor and Src in PC12 h cells. J Neurochem 83:1372-1379

Navarro HA, Mills E, Seidler FJ et al (1990) Prenatal nicotine exposure impairs beta-adrenergic function: persistent chronotropic subsensitivity despite recovery from deficits in receptor binding. Brain Res Bull 25:233-237

Nguyen KD, Qiu Y, Cui X et al (2011) Alternatively activated macrophages produce catecholamines to sustain adaptive thermogenesis. Nature 480:104-108

Nishi S, Seino Y, Ishida H et al (1987) Vagal regulation of insulin, glucagon, and somatostatin secretion in vitro in the rat. J Clin Investig 79:1191-1196

Noorchashm H, Kwok W, Rabinovitch A et al (1997) Immunology of IDDM. Diabetologia 40(Suppl 3):B50-B57

Ohtani M, Oka T, Badyuk M et al (2006) Mouse beta-TC6 insulinoma cells: high expression of functional alpha3beta4 nicotinic receptors mediating membrane potential, intracellular calcium, and insulin release. Mol Pharmacol 69:899-907

Ohtani M, Daly JW, Oka T (2009) Co-existence of muscarinic and nicotinic receptors and their functional interaction in mouse beta-TC6 cells. Eur J Pharmacol 604:150-157

Oke SL, Tracey KJ (2009) The inflammatory reflex and the role of complementary and alternative medical therapies. Ann N Y Acad Sci 1172:172-180

Oliff HS, Gallardo KA (1999) The effect of nicotine on developing brain catecholamine systems. Front Biosci 4:D883-D897

Oliveira E, Pinheiro CR, Santos-Silva AP et al (2010) Nicotine exposure affects mother's and pup's nutritional, biochemical, and hormonal profiles during lactation in rats. J Endocrinol 205:159-170

Ong KK, Preece MA, Emmett PM et al (2002) Size at birth and early childhood growth in relation to maternal smoking, parity and infant breast-feeding: longitudinal birth cohort study and analysis. Pediatr Res 52:863-867

Palma E, Conti L, Roseti C et al (2012) Novel approaches to study the involvement of alpha7-nAChR in human diseases. Curr Drug Targets 13:579-586

Pasumarthi RK, Fadel J (2010) Stimulation of lateral hypothalamic glutamate and acetylcholine efflux by nicotine: implications for mechanisms of nicotine-induced activation of orexin neurons. J Neurochem 113:1023-1035

Pasumarthi RK, Reznikov LR, Fadel J (2006) Activation of orexin neurons by acute nicotine. Eur J Pharmacol 535:172-176

Power C, Jefferis BJ (2002) Fetal environment and subsequent obesity: a study of maternal smoking. Int $\mathbf{J}$ Epidemiol 31:413-419

Raju TN (1999) The Nobel chronicles. 1936: Henry Hallett Dale (1875-1968) and Otto Loewi (1873-1961). Lancet 353:416

Rodriguez-Diaz R, Abdulreda MH, Formoso AL et al (2011a) Innervation patterns of autonomic axons in the human endocrine pancreas. Cell Metab 14:45-54

Rodriguez-Diaz R, Dando R, Jacques-Silva MC et al (2011b) Alpha cells secrete acetylcholine as a non-neuronal paracrine signal priming beta cell function in humans. Nat Med $17: 888-892$
Ruiz de Azua I, Gautam D, Jain S et al (2012) Critical metabolic roles of beta-cell M3 muscarinic acetylcholine receptors. Life Sci 91:986-991

Satapathy SK, Ochani M, Dancho M et al (2011) Galantamine alleviates inflammation and other obesity-associated complications in high-fat diet-fed mice. Mol Med 17:599-606

Seguela P, Wadiche J, Dineley-Miller K et al (1993) Molecular cloning, functional properties, and distribution of rat brain alpha 7: a nicotinic cation channel highly permeable to calcium. J Neurosci 13:596-604

Sha L, Love JA, Ma RC et al (1997) Cholinergic transmission in pancreatic ganglia of the cat. Pancreas 14:83-93

Sharma G, Vijayaraghavan S (2002) Nicotinic receptor signaling in nonexcitable cells. J Neurobiol 53:524-534

Sharp BM, Matta SG (1993) Detection by in vivo microdialysis of nicotine-induced norepinephrine secretion from the hypothalamic paraventricular nucleus of freely moving rats: dosedependency and desensitization. Endocrinology 133:11-19

Somm E, Schwitzgebel VM, Vauthay DM et al (2008) Prenatal nicotine exposure alters early pancreatic islet and adipose tissue development with consequences on the control of body weight and glucose metabolism later in life. Endocrinology 149:6289-6299

Somm E, Schwitzgebel VM, Vauthay DM et al (2009) Prenatal nicotine exposure and the programming of metabolic and cardiovascular disorders. Mol Cell Endocrinol 304:69-77

Sowan NA, Stember ML (2000) Effect of maternal prenatal smoking on infant growth and development of obesity. J Perinat Educ 9:22-29

Stagner JI, Samols E (1986) Modulation of insulin secretion by pancreatic ganglionic nicotinic receptors. Diabetes 35:849-854

Sun M, Lee CJ, Shin HS (2007) Reduced nicotinic receptor function in sympathetic ganglia is responsible for the hypothermia in the acetylcholinesterase knockout mouse. J Physiol 578(Pt 3): 751-764

Sztalryd C, Hamilton J, Horwitz BA et al (1996) Alterations of lipolysis and lipoprotein lipase in chronically nicotine-treated rats. Am J Physiol 270(2 Pt 1):E215-E223

Taly A, Charon S (2012) Alpha7 nicotinic acetylcholine receptors: a therapeutic target in the structure era. Curr Drug Targets 13:695-706

Toschke AM, Koletzko B, Slikker W Jr et al (2002a) Childhood obesity is associated with maternal smoking in pregnancy. Eur $\mathrm{J}$ Pediatr 161:445-448

Toschke AM, Vignerova J, Lhotska L et al (2002b) Overweight and obesity in 6- to 14-year-old Czech children in 1991: protective effect of breast-feeding. J Pediatr 141:764-769

Tracey KJ (2007) Physiology and immunology of the cholinergic antiinflammatory pathway. J Clin Investig 117:289-296

Unwin N (2005) Refined structure of the nicotinic acetylcholine receptor at 4A resolution. J Mol Biol 346:967-989

Uteshev VV (2012) Alpha7 nicotinic ACh receptors as a ligand-gated source of $\mathrm{Ca}(2+)$ ions: the search for a $\mathrm{Ca}(2+)$ optimum. $\mathrm{Adv}$ Exp Med Biol 740:603-638

Vaisse C, Halaas JL, Horvath CM et al (1996) Leptin activation of Stat 3 in the hypothalamus of wild-type and ob/ob mice but not $\mathrm{db} / \mathrm{db}$ mice. Nat Genet 14:95-97

van Marken Lichtenbelt WD, Vanhommerig JW, Smulders NM et al (2009) Cold-activated brown adipose tissue in healthy men. N Engl J Med 360:1500-1508

Wada E, Wada K, Boulter J et al (1989) Distribution of alpha 2, alpha 3 , alpha 4 , and beta 2 neuronal nicotinic receptor subunit mRNAs in the central nervous system: a hybridization histochemical study in the rat. J Comp Neurol 284:314-335

Wang N, Orr-Urtreger A, Korczyn AD (2002) The role of neuronal nicotinic acetylcholine receptor subunits in autonomic ganglia: lessons from knockout mice. Prog Neurobiol 68:341-360 
Wang H, Yu M, Ochani M et al (2003) Nicotinic acetylcholine receptor alpha7 subunit is an essential regulator of inflammation. Nature 421:384-388

Wang X, Yang Z, Xue B et al (2011) Activation of the cholinergic antiinflammatory pathway ameliorates obesity-induced inflammation and insulin resistance. Endocrinology 152:836-846

Weisberg SP, McCann D, Desai M et al (2003) Obesity is associated with macrophage accumulation in adipose tissue. J Clin Investig 112:1796-1808

West KA, Brognard J, Clark AS et al (2003) Rapid Akt activation by nicotine and a tobacco carcinogen modulates the phenotype of normal human airway epithelial cells. J Clin Investig 111:81-90

Williams CM, Kanagasabai T (1984) Maternal adipose tissue response to nicotine administration in the pregnant rat: effects on fetal body fat and cellularity. Br J Nutr 51:7-13

Winders SE, Grunberg NE (1990) Effects of nicotine on body weight, food consumption and body composition in male rats. Life Sci 46:1523-1530

Woods SC, Porte D Jr (1974) Neural control of the endocrine pancreas. Physiol Rev 54:596-619

Xu H, Barnes GT, Yang Q et al (2003) Chronic inflammation in fat plays a crucial role in the development of obesity-related insulin resistance. J Clin Investig 112:1821-1830
Xu TY, Guo LL, Wang P et al (2012) Chronic exposure to nicotine enhances insulin sensitivity through alpha7 nicotinic acetylcholine receptor-STAT3 pathway. PLoS ONE 7:e51217

Yang ZJ, Blaha V, Meguid MM et al (1999) Infusion of nicotine into the LHA enhances dopamine and 5-HT release and suppresses food intake. Pharmacol Biochem Behav 64:155-159

Yang J, Zhu Y, Cole SA et al (2012) A gene-family analysis of 61 genetic variants in the nicotinic acetylcholine receptor genes for insulin resistance and type 2 diabetes in American Indians. Diabetes 61:1888-1894

Yoshida T, Yoshioka K, Hiraoka N et al (1990) Effect of nicotine on norepinephrine turnover and thermogenesis in brown adipose tissue and metabolic rate in MSG obese mice. J Nutr Sci Vitaminol 36:123-130

Yoshida T, Sakane N, Umekawa T et al (1999) Nicotine induces uncoupling protein 1 in white adipose tissue of obese mice. Int $\mathbf{J}$ Obes Relat Metab Disord 23:570-575

Yoshikawa H, Hellstrom-Lindahl E, Grill V (2005) Evidence for functional nicotinic receptors on pancreatic beta cells. Metabolism 54:247-254

Zoli M, Picciotto MR (2012) Nicotinic regulation of energy homeostasis. Nicotine Tob Res 14:1270-1290 